\title{
Serum Thyrotropin Response to Thyrotropin Releasing Hormone and the Concentration of Thyroid Hormone in Patients with Hyperfunctioning Thyroid Nodule
}

\author{
KIYOSHI MIYAI, SHINICHIRo TAKAI, ${ }^{*}$ KANJI KUMA, ** \\ Mizuo AZUKIZAWA, KaICHIRo ISHIBASHI, Mitsuko HOSOKAWA, \\ AND YUICHI KUMAHARA \\ Central Laboratory for Clinical Investigation, \\ Second Department of Surgery, ${ }^{*}$ Osaka University Medical School, \\ Osaka 553, and Kuma Hospital ${ }^{* *}$, Kobe 650
}

\begin{abstract}
Synopsis
Relationship between serum TSH response to TRH and serum thyroid hormone levels was studied in 8 patients with single hyperfunctioning nodule of thyroid. The results were variable. No or low response to $500 \mu \mathrm{g}$ TRH was observed in 6 subjects, 3 of whom were associated with evevated $T_{4}$ and $T_{3}$, one with normal $T_{4}$ and elevated $T_{3}$ and two with normal $T_{4}$ and $T_{3}$. Normal response was shown in other 2 subjects with normal $T_{4}$ and $\mathrm{T}_{3}$. Following administration of $2,000 \mu \mathrm{g}$ TRH to 3 subjects with absence of response to $500 \mu \mathrm{g}$ TRH, 2 subjects with elevated $\mathrm{T}_{4}$ and $\mathrm{T}_{3}$ showed no response, but one with normal $\mathrm{T}_{4}$ and $\mathrm{T}_{3}$ showed low but definite response. After removal of the nodule, TSH response to $\mathrm{TRH}$ was increased in 3 subjects. Two of them was associated with decreased $T_{4}$ and $T_{3}$ but another one showed negligible changes in $T_{4}$ and $T_{3}$. These findings may indicate that responsiveness of TSH to TRH in these patients is not solely dependent on circulating thyroid hormone levels.
\end{abstract}

A hyperfunctioning nodular goiter is characterized by hyperfunction of the nodular tissue associated with hypofunction of the remainder of the normal tissue. Such a state is demonstrable by thyroid scanning. Radioiodine accumulation of the normal area when it remains, is suppressed, by thyroid hormone or when it is suppressed, it is restored by TSH, while that of the nodular area is unchanged (Sheline and McCormack, 1960). These findings suggest that the autonomous nodular tissue produces excess thyroid hormone which in turn suppresses the function of the remaining normal thyroid tissue by negative feedback mechanism. Recently, synthetic thyrotropin-releasing hormone (TRH) has been used for the evaluation of TSH secretion in man. Lack of response of serum TSH to TRH administration has been shown in some thyroid disorders,

Received for publication June 7, 1974. such as diffuse toxic goiter (Kumahara et al., 1971; Lawton et al., 1971; Ormston et al., 1971; Shenkman et al., 1973) or subacute thyroiditis during acute phase (Ogihara et al., 1973). As an analogy of these thyroid disorders, Karlberg (1973) and Ridgway et al. (1973) has demonstrated an absent TSH response to TRH in patients with single thyroid nodule, either in hyperthyroid or even in euthyroid state. Although triiodothyronine $\left(\mathrm{T}_{3}\right)$ has been known to be an important modulator of responsiveness to TRH (Snyder and Utiger 1972a; Shenkman et al., 1973), serum $T_{3}$ concentration has been found to be normal (Ridgway et al., 1973).

In the present study, pituitary responsiveness to TRH was examined in patients with solitary hyperfunctioning thyroid nodule in various thyroid conditions including that before and after removal of the nodule, and the relationship between their responsiveness to TRH 
and thyroid states judged by serum thyroxine $\left(\mathrm{T}_{4}\right)$ and $\mathrm{T}_{3}$ were discussed.

\section{Materials and Methods}

Eight patients with solitary hyperfunctioning nodule of the thyroid were studied. Their thyroid states are summarized in Tables 1 and 2.

TSH response to TRH was determined as previously described (Kumahara et al., 1971). TRH used in this study was synthesized by Dr. Shinpei Sakaki- bara, Peptide Institute, Protein Research Foundation Osaka, and the preparation for injection was prepared by Tanabe Seiyaku Co., Ltd. Blood was withdrawn before, 30, 60 and $120 \mathrm{~min}$ after intravenous injection of $500 \mu \mathrm{g}$ of TRH. In 3 cases, $2000 \mu \mathrm{g}$ of TRH was given separately. Radioimmunoassay of TSH was performed by the double antibody method as described by Patel et al. (1971) using a commercial kit of Daiichi Radioisotope Laboratories (reagents were provided from Calbiochem.). Serum $T_{3}$ was measured by radioimmunoassay according to Lieblich and Utiger (1972) using anti- $T_{3}$ rabbit serum which was made in our laboratory. The thyroid function tests

Table 1. Scintiscanning and histological findings of patients with hyperfunctioning thyroid nodule.

\begin{tabular}{|c|c|c|c|c|c|}
\hline Subjects & Age, Sex & $\begin{array}{l}\text { Extirpation } \\
\text { of nodule }\end{array}$ & $\begin{array}{l}\text { Goiter Size } \\
\quad(\mathrm{cm})\end{array}$ & Scintigram & $\begin{array}{l}\text { Histological } \\
\text { findings of nodule }\end{array}$ \\
\hline 1. T.K. & $39, \mathrm{~F}$ & before & $4.0 \times 2.5$ & $\begin{array}{l}\text { left hot nodule } \\
\text { diffuse uptake after TSH }\end{array}$ & \\
\hline 2. S.Y. & $50, \mathrm{~F}$ & before & $5.0 \times 3.5$ & $\begin{array}{l}\text { left hot nodule } \\
\text { diffuse uptake after TSH }\end{array}$ & \\
\hline 3. S.G. & $64, \mathrm{M}$ & $\begin{array}{l}\text { before } \\
\text { after }(1 \mathrm{mo} .)\end{array}$ & $5.4 \times 4.0$ & $\begin{array}{l}\text { left hot nodule } \\
\text { diffuse uptake after TSH } \\
\text { diffuse uptake by right side }\end{array}$ & $\begin{array}{l}\text { tubular adenoma with } \\
\text { adenomatous cystic } \\
\text { goiter }\end{array}$ \\
\hline 4. K.S. & $21, \mathrm{~F}$ & $\begin{array}{l}\text { before } \\
\text { after }(1 \mathrm{mo} .)\end{array}$ & $3.5 \times 3.5$ & $\begin{array}{l}\text { middle-hot nodule } \\
\text { diffuse uptake after TSH } \\
\text { diffuse uptake }\end{array}$ & tubular adenoma \\
\hline 5. Y.S. & $62, F$ & before & $3.0 \times 3.0$ & $\begin{array}{l}\text { left hot nodule } \\
\text { diffuse uptake after TSH }\end{array}$ & \\
\hline 6. M.K. & $23, \mathrm{~F}$ & $\begin{array}{l}\text { before } \\
\text { after }(4 \mathrm{mo} .)\end{array}$ & $4.0 \times 2.0$ & $\begin{array}{l}\text { right warm nodule } \\
\text { hot nodule after } T_{3} \\
\text { diffuse uptake by left side }\end{array}$ & follicular adenoma \\
\hline 7. S.S. & $40, \mathrm{~F}$ & before & $2.8 \times 1.8$ & $\begin{array}{l}\text { right warm nodule } \\
\text { diffuse uptake after TSH }\end{array}$ & adenomatous goiter \\
\hline 8. S.O. & $49, \mathrm{~F}$ & $\begin{array}{l}\text { after }(8 \mathrm{mo} .) \\
\text { before }\end{array}$ & $4.2 \times 3.0$ & $\begin{array}{l}\text { diffuse uptake by left side } \\
\text { left warm nodule } \\
\text { left hot nodule after } T_{3} \\
\text { diffuse uptake after TSH }\end{array}$ & \\
\hline
\end{tabular}

mo: month.

Table 3. TSH response to $500 \mu \mathrm{g}$ and $2,000 \mu \mathrm{g}$ TRH administration

\begin{tabular}{cccccc}
\hline \multirow{2}{*}{ Subjects } & $\begin{array}{c}\text { Dose of TRH } \\
(\mu \mathrm{g})\end{array}$ & \multicolumn{4}{c}{ TSH $(\mu \mathrm{U} / \mathrm{m} l)$ after TRH } \\
\cline { 3 - 5 } & 500 & $<1.0$ & $<1.0$ & $<0$ & $120 \mathrm{~min}$ \\
\hline 1. T.K. & 2,000 & $<1.0$ & $<1.0$ & $<1.0$ & $<1.0$ \\
& 500 & $<1.0$ & $<1.0$ & $<1.0$ & $<1.0$ \\
2. S.Y. & 2,000 & $<1.0$ & $<1.0$ & $<1.0$ & $<1.0$ \\
& 500 & $<1.0$ & $<1.0$ & $<1.0$ & $<1.0$ \\
5. Y.S. & 2,000 & $<1.0$ & 4.3 & 3.2 & 3.5 \\
\hline
\end{tabular}


were performed using the standard procedures as follows: basal metabolic rate (BMR) by Sanborn's metabulator, $\mathrm{T}_{4}$ by competitive protein binding analysis using Tetralute kit (Ames Co.,), ${ }^{131} \mathrm{I}_{-} \mathrm{T}_{3}$ resin sponge uptake $\left(\mathrm{RT}_{3} \mathrm{U}\right)$ by Triosorb test kit (Dainabot Radioisotope Laboratories). The normal values of these tests in our laboratory are listed in Table 2.

\section{Results}

As shown in Table 2, results of serum TSH response to TRH and the thyroid function tests were variable. The basal levels of serum TSH were negligible and did not rise to normal limits after $500 \mu \mathrm{g}$ TRH administration in 6 subjects; cases 1-3 with elevation in both serum $T_{4}$ and $T_{3}$, case 4 with normal $T_{4}$ and elevated $T_{3}$, and cases 5 and 6 with normal $T_{4}$ and $T_{3}$. In the other 2 subjects (cases 7 and 8 ) with normal $T_{4}$ and $T_{3}$, basal TSH was detectable, and normal responses to TRH were observed. Thyroid scintiscans disclosed hot nodule in cases $1-5$ without response to TRH and warm nodule in cases 6-8 with response to TRH (Table 1). As shown in Table 3, administration of $2000 \mu \mathrm{g}$ TRH did not cause response of TSH in cases 1 and 2 with elevated $\mathrm{T}_{4}$ and $\mathrm{T}_{3}$ but caused definite response in case 5 with normal $\mathrm{T}_{4}$ and $\mathrm{T}_{3}$.

After surgical extirpation of the nodule, TSH response to TRH was significantly increased in 3 out of 4 subjects. (Table 2) In case 3 , low but definite response to TRH with decreased $T_{4}$ and $T_{3} 1$ month after operation became supernormal response to $\mathrm{TRH}$ with normalized $T_{4}$ and $T_{3}$ after 6 months. In case 4 , response to TRH and serum levels of $\mathrm{T}_{4}$ and $\mathrm{T}_{3}$ were normalized after 6 months. In case 6 , response to TRH was increased with slight or negligible changes in $T_{4}$ and $T_{3}$.

\section{Discussion}

Lack of TSH response to TRH was observed in patients with hyperfunctioning thyroid nodule, with elevated $\mathrm{T}_{4}$ and even with normal
$T_{4}$. Karlberg (1973) has also demonstrated no response to $\mathrm{TRH}$ in clinically euthyroid patients with normal $T_{4}$, and he suggested $T_{3}$ hypersecretion in such patients. It is also considered that thyroid adenomas may secrete more $T_{3}$ than $T_{4}$ (Hollander et al., 1972) although $T_{3}$ content in the adenomas tissue was not found to be increased (Larsen et al., 1973). Present work has demonstrated a patient with " $T_{3}$ toxicosis" without response to TRH. The finding is consistent with a hypothesis that circulating $T_{3}$ is an important modulator of pituitary responsiveness to TRH (Shenkman et al., 1973). The reason why cases 1-3 had normal $\mathrm{RT}_{3} \mathrm{U}$ remains unclear.

On the other hand, 2 patients (cases 5 and 6) showed no or low response to TRH in spite of the normal concentration of circulating $T_{4}$ and $T_{3}$. The free $T_{4}$ and $T_{3}$ concentrations have been found to be normal in such subjects (Ridgway et al., 1973). There was no dose related response beyond a dose of $400 \mu \mathrm{g} \mathrm{TRH}$ in normal man (Snyder and Utiger 1972b). In case 5, however, there was no response to $500 \mu \mathrm{g}$ TRH but a definite response to $2000 \mu \mathrm{g}$ TRH. Bowers et al. (1967) demonstrated that increasing the dose of TRH overcome the inhibition caused by $\mathrm{T}_{4}$ in mice. It is suggested that only minimal increases in thyroid hormone concentration in blood and/or pituitary gland inhibit TSH response to TRH in these subjects. There was no differences in age, sex, duration of illness, size and histological findings of goiter between responders (cases 7 and 8) and non-responders (cases 5 and 6).

After removal of the nodule, $\mathrm{T}_{4}$ and $\mathrm{T}_{3}$ levels decreased and response to TRH increased, but the course was variable. In case 6 , response to $\mathrm{TRH}$ was significantly increased after operation but changes in $T_{4}$ and $T_{3}$ levels were slight or negligible. One possible explanation for this phenomenon is that, before operation, an excess amount of thyroid hormone which is secreted from the autonomous nodule causes inhibition of TSH secretion and in turn suppresses production of thyroid hormone by the remainder of the 


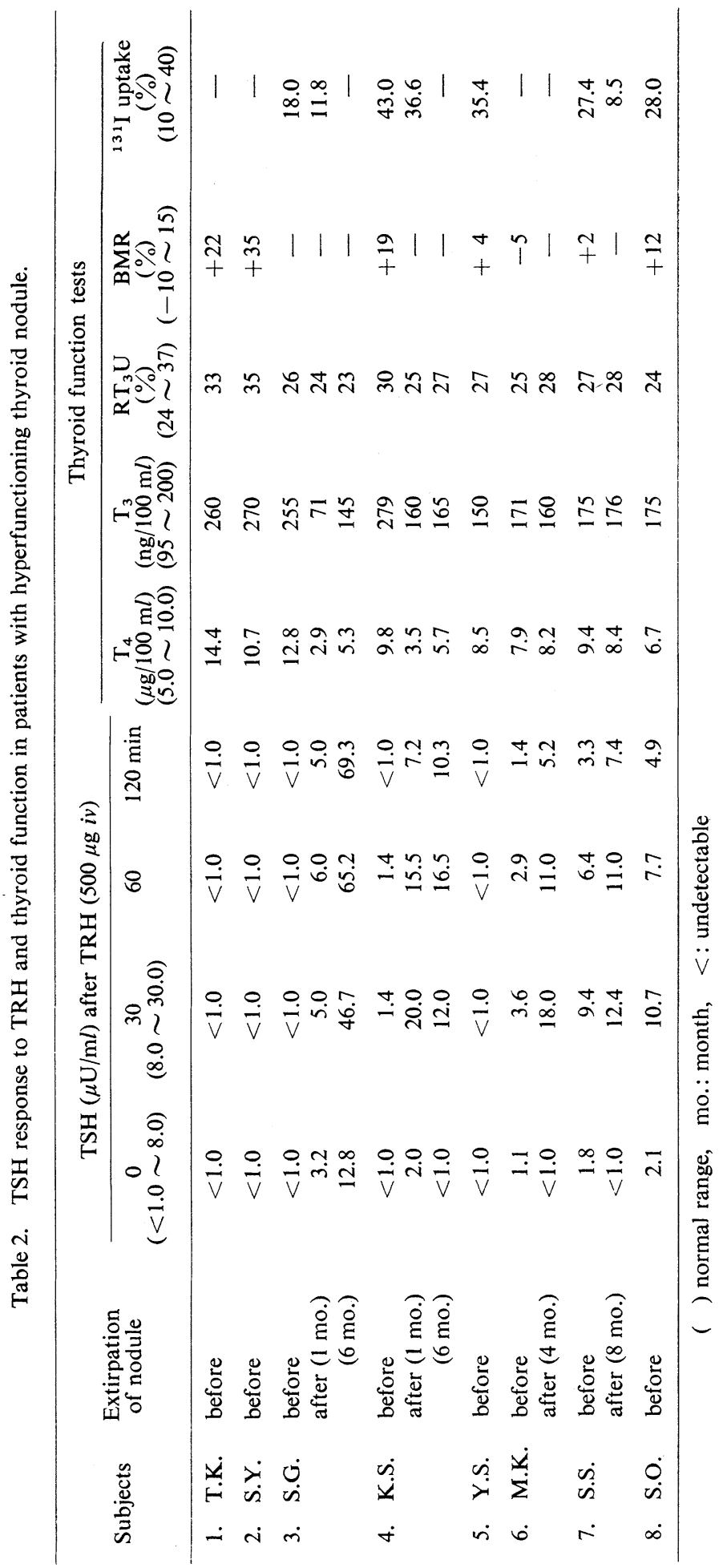


normal thyroid tissue, thus the total thyroid hormone secretion does not so increase, whereas after operation, thyroid hormone was secreted from the normal thyroid tissue under stimulation of TSH, thus the thyroid hormone level does not so decrease. Changing in pattern of the scintigram before and after operation also indicates such a situation. It is also noticeable that the TRH test is useful to detect an abnormal state in which the thyroid hormone is secreted from abnormal thyroid tissus such as hyperfunctioning nodule or ectopic thyroid, or the normal thyroid is stimulated by an extra-pituitary thyroid stimulator such as human chorionic thyrotropin, ectopic thyrotropin, or by a long acting thyroid stimulator.

\section{Acknowledgements}

We wish to express our thanks to Dr. Toshio Ohishi for permission to study a patient under his care, to Dr. Canada Ito for his help in preparing this manuscript in English. We also owe much to Medical Research Council, National Institute for Medical Research for providing standard TSH.

\section{References}

Bowers, C. Y., A. V. Schally, G. A. Reynolds and W. D. Hawley (1967). Endocrinology 81, 741 .
Hollander, C. S., T. Mitsuma, N. Nihei, L. Shenkman, S. Z. Burday and M. Blum (1972). Lancet 1, 609.

Karlberg, B. E. (1973). Acta Endocr. 73, 689.

Kumahara, Y., K. Miyai and M. Azukizawa (1971). Med. J. Osaka Univ. 22, 97.

Larsen, P. R., K. Yamashita, A. Dekker and J. B. Field (1973). J. Clin. Endocrinol. Metab. 36, 1009.

Lawton, N. F., R. P. Ekins and J. D. N. Nabarro (1971). Lancet 2, 14.

Lieblich, J. and R. D. Utiger (1972). J. Clin. Invest. 51, 157.

Ogihara, T., T. Yamamoto, M. Azukizawa, K. Miyai and Y. Kumahara (1973). J. Clin. Endocrinol. Metab. 37, 602.

Ormston, B. J., R. Garry, R. J. Cryer, C. M. Besser and R. Hall (1971). Lancet 2, 10.

Patel, Y. C., H. G. Burger and B. Hudson (1971). J. Clin. Endocrinol. Metab. 33, 768.

Ridgway, E. C., B. D. Weintraub, J. L. Cevallos, M. C. Rack and F. Maloof (1973). J. Clin. Invest. 52, 2783.

Sheline, G. E. and K. McCormack (1960). J. Clin. Endocrinol. Metab. 20, 1401.

Shenkman, L., T. Mitsuma and C. S. Hollander (1973). J. Clin. Invest. 52, 205.

Snyder, P. J. and R. D. Utiger (1972a). J. Ibid 51, 2077.

Snyder, P. J. and R. D. Utiger (1972b). J. Clin. Endocrinol. Metab. 34, 380. 